\title{
JUAL BELI RAMUAN TRADISIONALMASYARAKAT DAYAK PERSPEKTIF BELOM BAHADAT DAN ETIKA BISNIS SYARIAH \\ (STUDI KASUS DI PASAR KAHAYAN KOTA PALANGKA RAYA)
}

\author{
Jefry Tarantang dan Bella Mutiara Kasih \\ Institut Agama Islam Negeri Palangka Raya
}

\begin{abstract}
Abstrak
Penelitian ini merupakan penelitian mengenai praktik jual beli masyarakat Dayak dalam menjual ramuan tradisional di pasar Kahayan kota Palangka Raya dilakukan para pedagang yang berumur di atas 55 tahun di karenakan kematangan pengetahuan yang dimiliki para pedagang, selain itu tidak semua masyarakat asli suku Dayak memiliki pengetahuan tentang ramuan tradisional ini, karena tidak ada sumber tertulis yang dapat dijadikan pedoman mereka. Hanya mengandalkan bakat turun-temurun dari para leluhur mereka. Etika jual beli masyarakat Dayak dalam berdagang ramuan tradisional adalah terdapat penerapan falsafah Belom Bahadat pada praktik jual beli mereka. Peneliti menyimpulkan terdapat prinsip tolong-menolong yang amat kuat dan dijunjung tinggi oleh pedagang yang merupakan masyarakat adat Dayak, dengan slogan mereka yaitu Handep tuntung haduhup yang artinya menanggulangi masalah bersama dan saling tolong-menolong. Jual beli ramuan tradisional masyarakat dayak di Pasar Kahayan Kota Palangka Raya perspektif belom bahadat dan etika bisnis syariah terdapat adanya kesamaan antara filosofi Belom Bahadat, yaitu hidup bertata krama dan beradab dan hidup dalam kedamaian, kebersamaan, kesetaraan, keharmonisan, toleransi, menjunjung tinggi hukum dan kerja sama untuk meraih kesejahteraan bersama yang diaplikasikan dalam etika jual beli masyarakat Dayak dalam berdagang ramuan tradisional dengan etika bisnis syariah antara lain adanya prinsip Ketuhanan, rahmatan lil alamin (rahmat bagi seluruh alam), tahqiq 'adl (mewujudkan keadilan), nubuwwah (kenabian). As-siddiq (transparansi), freedom to act (kebebasan dalam bertindak dan berusaha) dan socio-profit oriented.
\end{abstract}

\section{Kata Kunci: ramuan tradisional, belom bahadat, dan etika bisnis syariah}

\section{PENDAHULUAN}

Masyarakat Dayak Kalimantan Tengah memiliki filosofi hidup belom bahadat ${ }^{1}$ yaitu tradisi hidup beradaptasi dengan alam dan lingkungan sehingga hutan, tanah, dan ngarai di Kalimantan Tengah merupakan sumber kehidupan mereka, tempat berburu, memancing ikan, mengambil manfaat hasil hutan untuk kepentingan kehidupan mereka serta obat-obatan dari hasil hutan di lingkungan tempat tinggal mereka. Oleh sebab itu, mereka menjaga alam lingkungan dengan sebaik-baiknya untuk kelangsungan hidup mereka dengan ketentuan yang sudah turun-temurun mereka dapatkan dari warisan leluhur mereka, sehingga muncullah filosofi masyarakat Dayak dengan istilah Belom Bahadat. Filosofi Belom Bahadat ini memiliki makna yang sangat luas dan mendalam menyangkut berbagai aspek kehidupan baik hubungan manusia dengan Tuhan, hubungan manusia dengan sesama manusia, dan hubungan manusia dengan alam lingkungan. Hubungan manusia dengan Tuhan yaitu menyangkut peribadatan, dimana orang Dayak tidak

\footnotetext{
${ }^{1}$ Belom Bahadat artinya hidup bertata krama dan beradab dan“Belom Penyang Hinje Simpei” (hidup dalam kedamaian, kebersamaan, kesetaraan, keharmonisan, toleransi, menjunjung tinggi hukum dan kerja sama untuk meraih kesejahteraan bersama. Lihat dalam Ibnu Elmi A.S. Pelu, dan Jefry Tarantang, Interkoneksi Nilai-Nilai Huma Betang Kalimantan Tengah dengan Pancasila, Jurnal Studi Agama dan Masyarakat, Volume 14, Nomor 2, Desember 2018, h. 123.
} 
akan mengganggu dan mengusik seseorang yang sedang beribadah kepada Tuhan nya masingmasing, hubungan manusia dengan sesama manusia yaitu terjadinya interaksi baik dalam silaturahmi, kegotongroyongan maupun masalah jual beli tanpa dibatasi oleh perbedaan suku, ras, dan agama. Adapun hubungan manusia dengan alam yaitu masyarakat Dayak memiliki ketergantungan baik pada sumber daya hutan, air, dan tanah, karena dari ketiga unsur tersebut mereka dapat hidup dengan hasil alam guna menopang perekonomian mereka.

Tanah, sungai dan hutan adalah tiga elemen terpenting yang memungkinkan sesorang hidup sebagai orang Dayak sejati. Selama berabad-abad 3 elemen ini telah membentuk sebuah identitas yang unik yang kita kenal sekarang sebagai orang Dayak. Hampir 80\% masyarakat adat (Indigenous Peoples) Dayak di Kalimantan mata pencahariannya berladang. Aktifitas berladang tidak bisa terlepas dari hutan. ${ }^{2}$ Tanpa hutan, maka tidak akan ada ladang. Selain itu dalam hubungan interaksi dengan sesama manusia masyarakat Dayak juga sebagian ada yang berjual beli antara lain menjual hasil alam, termasuk tumbuh-tumbuhan herbal yang didapat dari hutan dan berfungsi untuk kesehatan manusia yang mereka sebut dengan ramuan Dayak. Jenis tanaman herbal yang dijadikan obat-obatan (ramuan Dayak) diperoleh dari pedalaman Kalimantan Tengah Hulu Barito, dalam pencariannya memerlukan waktu yang sangat lama, masuk ke dalam hutan memakan waktu berhari-hari untuk memperoleh jenis ramuan yang berkhasiat untuk kesehatan.

Konteksnya dengan pemanfaatan Himba atau hutan untuk Tatamba atau obat-obatan masih dilakukan oleh masyarakat Adat Dayak Ngaju di wilayah DAS Kahayan, obat-obatan yang diambil dari hutan antara lain Pasak Bumi, Saluang Belum, Bajakah Pari dan Kalapap, Uhat Kalamambung dan Uhat Rokam, serta berbagai macam jenis tumbuhan lainnya. ${ }^{3}$ Berdasarkan hasil observasi peneliti kepada pedagang obat tradisional masyarakat Dayak di Pasar Kahayan mereka menyampaikan bahwa hasil obat-obatan tradisional tersebut sejatinya sudah banyak yang punah karena alih fungsi hutan ke kelapa sawit melalui kebijakan pemerintah, sehingga tanaman-tanaman herbal yang tidak ditemukan lagi di dalam hutan mereka budidayakan di perkebunan di lahan pribadi mereka. Dengan di budidaya tersebut mereka masih bisa melakukan jual beli ramuan tradisional untuk dijual kepada masyarakat yang memerlukan. ${ }^{4}$

Ada keunikan tersendiri dalam pengamatan peneliti bahwa penjual ramuan herbal yang di jual oleh pedagang masyarakat Dayak di Pasar Kahayan penjualnya rata-rata orang tua. Ketika peneliti menanyakan kenapa para penjualnya rata-rata orang tua, mereka menjawab bahwa orang tua lah yang paham betul tentang jenis obat herbal yang mereka jual dan kegunaannya dalam mengobati penyakit yang diderita, sedangkan anak-anak mereka yang masih muda tidak berminat untuk menekuni dagangan tradisional yang dikelola oleh orang tua mereka. ${ }^{5}$ Terkait dengan praktik jual beli ramuan herbal oleh pedagang masyarakat Dayak di Pasar Kahayan ini ada beberapa hal yang menarik untuk dikaji dalam etika jual beli, yaitu: jika dalam praktik jual beli ramuan herbal antara pembeli dengan pedagang terjadi kesalahan pemesanan dalam pembelian jenis ramuan pada toko mereka maka pedagang orang dayak ini bersedia ditukarkan barangnya dengan barang yang diperlukan asalkan kondisi barang yang dipertukarbelikan itu dalam kondisi tidak rusak, selain itu jika ada konsumen yang tidak memiliki uang namun sangat membutuhkan ramuan yang mereka jual, maka pedagang orang Dayak yang menjual ramuan herbal khas Dayak di Pasar Kahayan bersedia memberikan ramuan tersebut secara sukarela.

\footnotetext{
2 Arif, Hutan : Darah dan Jiwa Dayak https://staff.blog.ui.ac.id/arif51/2008/09/02/hutan-darah-dan-jiwa-dayak/ Di akses pada 18 Februari 2018.

${ }^{3}$ Salmon Batuallo, Peranan Nilai Budaya Masyarakat Dayak Ngaju dalam Memelihara Lingkungan Di Provinsi Kalimantan Tengah, Pontianak : Balai Pelestarian Sejarah dan Nilai Tradisional Pontianak Wilayah Kalimantan, 2009, hlm. 41.

${ }^{4}$ Observasi sekaligus wawancara dengan EY sebagai salah satu penjual ramuan tradisional khas Dayak di pasar Kahayan kota Palangka Raya.

${ }^{5}$ Observasi sekaligus wawancara dengan MN sebagai salah satu pedagang ramuan tradisional di pasar Kahayan kota Palangka Raya.
} 
Selanjutnya dalam praktik jual beli mereka tidak mengambil untung yang banyak yang penting mereka bisa membantu orang menyembuhkan penyakit yang diderita melalui obat-obatan tradisional yang mereka ramu sendiri sehingga dalam konteks etikayaitu karakter, watak, kesusilaan, ${ }^{6}$ secara khusus mengenai etika bisnis syariah memiliki prinsip Ketuhanan, rahmatan lil 'alamin(rahmatbagi seluruh alam), tahqiq 'adl (mewujudkan keadilan), nubuwwah (kenabian), as-siddiq (transparansi), freedom to act (kebebasan bertindak dan berusaha) dan socio-profit oriented. Ekonomi Islam meletakkan manusia sebagai khalifah dimuka bumi ini dimana segala bahan-bahan yang ada dibumi dan di langit adalah diperuntukkan untuk manusia. ${ }^{7}$

\section{PEMBAHASAN}

\section{Praktik Jual Beli Ramuan Tradisional Masyarakat Dayak di Pasar Kahayan Kota Palangka Raya}

Praktik jual beli ramuan tradisional oleh masyarakat Dayak hanya dilakukan oleh sebagian kecil masyarakat Dayak yang berusia di atas 55 tahun, yang memiliki keahlian turun-temurun dengan melalui proses belajar selama berpuluh-puluh tahun, dan tidak semua masyarakat Dayak menekuni ini. Menurut Salmon Batuallo bahwa pengalaman manusia yang diperoleh selama beradaptasi dengan lingkungan alam akhirnya menimbulkan berbagai pengetahuan tentang lingkungannya yang mencakup tidak hanya sumber daya pangan, tetapi juga sumber daya yang langsung maupun tidak langsung mendukung kehidupan manusia. Oleh karena itu masyarakat Dayak Ngaju mempersepsikan lingkungan alam, baik manusia, binatang, tumbuh-tumbuhan, sungai, hutan serta berbagai sumber alam perlu dijaga. ${ }^{8}$

Terkait dengan tata cara dan resep meracik ramuan yang diperjualbelikan oleh pedagang ramuan tradisional tersebut tidak terdapat pengetahuan secara tertulis, melainkan berdasarkan pengetahuan yang diperoleh secara khusus oleh masyarakat Dayak melalui para leluhurnya. Tumbuh-tumbuhan dari hutan yang selama ini dimanfaatkan oleh masyarakat adat Dayak sebagai obat-obatan, semakin terancam punah sehingga semakin sulit dicari dan ditemukan karena kondisi hutan yang semakin menyusut. Untuk tanaman herbal yang bisa dibudidayakan hanya bawang Dayak saja, selebihnya harus didapatkan langsung dari hutan. Berdasarkan bahasan tersebut, jika dihubungkan dengan kajian teori nilai yang berbicara tentang tingkah laku manusia yang menentukan perilaku baik-buruk di dalam kehidupannya. ${ }^{9}$ Sedangkan dalam kajian sosiolog, etika merupakan adat kebiasaan dan perilaku orang-orang dari lingkungan budaya tertentu ${ }^{10}$, jika dihubungkan dengan adat dan kebiasaan masyarakat suku Dayak yang berprofesi sebagai pedagang ramuan tradisional khas Dayak, yang selalu menjaga kelestarian lingkungannya karena mereka beranggapan bahwa lingkungan alam merupakan sumber kehidupan manusia yang patut dijaga dan dirawat antara lain sumber daya hutan menumbuhkan berbagai tanaman obat-obatan tradisional yang bermanfaat bagi manusia.

Berdasarkan uraian di atas tergambar bahwa sangat pentingnya menjalin harmonisasi manusia dengan alam karena jika manusia berperilaku baik dengan alam lingkungan, maka alam tersebut akan memberikan banyak nilai manfaat bagi kelangsungan hidup manusia sebagaimana ramuan tradisional khas Dayak sebagai bukti dari hasil lingkungan yang masih terjaga kelestariannya. Kaitannya dengan filosofi suku Dayak Ngaju dalam pelaksanaan perilaku hidup Belom Bahadat, maka akan teraktualisasi Belom Penyang Hinje Simpei yaitu hidup

${ }^{6}$ Jefry Tarantang, Menggali Etika Pengacara dalam Alquran, Jurnal Studi Agama dan Masyarakat, Volume 11, Nomor 2, Desember 2015, hlm. 147.

${ }^{7}$ Observasi sekaligus wawancara dengan MN sebagai salah satu pedagang ramuan tradisional di pasar Kahayan kota Palangka Raya ${ }^{8}$ Salmon Batuallo...,hlm. 48.

${ }^{9}$ M. Yatimin Abdullah, Pengantar Studi Etika, Jakarta : PT. Raja Grafindo Persada, 2006, hlm. 535.

${ }^{10}$ Zaim El Mubarak, Membumikan Pendidikan Nilai (Mengumpulkan yang terserak, menyambung yang terputus, dan menyatukan yang tercerai), Bandung: Penerbit Alfabeta, 2008, hlm. 28. 
berdampingan, rukun dan damai untuk kesejahteraan bersama. ${ }^{11}$ Penyang Hinjei Simpei merupakan istilah dari bahasa Dayak Ngaju yang secara harfiah berarti rukun dan damai demi kesejahteraan bersama. Dalam tatanan keseharian, istilah ini menjadi belum penyang hinjei simpei terlaksana dengan baik, kerusakan alam, keserakahan manusia, malapetaka dan hal-hal buruk bisa dihindari. ${ }^{12}$

Berdasarkan pencermatan peneliti, masyarakat suku Dayak sangat dekat dengan alam, bahkan bisa dikatakan bergantung dengan alam. Hal ini sebagaimana dalam perjalanan penelitian peneliti mendapati salah seorang masyarakat asli suku Dayak menjelaskan bahwa masyarakat Dayak pada umumnya dimanjakan oleh alam, kalaupun dalam hal berjual beli, mereka tidak dapat dikatakan mencari keuntungan sebesar-besarnya, tetapi hanya sekedar cukup untuk memenuhi kebutuhan hidup mereka dan saling tolong-menolong kepada orang lain dengan talenta yang mereka miliki salah satunya keahlian sebagian mereka (suku Dayak) mengetahui jenis-jenis ramuan tradisional yang terdapat didalam hutan Kalimantan Tengah. Oleh karena itu menurut peneliti bahwa cara masyarakat Dayak menjual ramuan tradisionalnya kepada konsumen dipasar kahayan tidak mengandung unsur propaganda dan mencari keuntungan yang sebesar-besarnya.

Pengamatan yang sudah peneliti lakukan ditemukan bahwa para pedagang dalam praktik jual belinya tersebut terlihat kesehariannya selalu tenang, berwajah tentram meskipun tidak semua orang yang berlalu-lalang didepan lapak jualan mereka tidak semuanya membeli apa yang mereka jual. Dalam konteks teori keadilan bahwa jika seseorang mengakui hak hidup orang lain, maka orang tersebut wajib mempertahankan hak hidupnya dan mengakui keberadaannya secara layak, sebab orang lain pun mempunyai hak hidup yang sama juga. ${ }^{13}$ Sejalan dengan firman Allah SWT yang berbunyi:

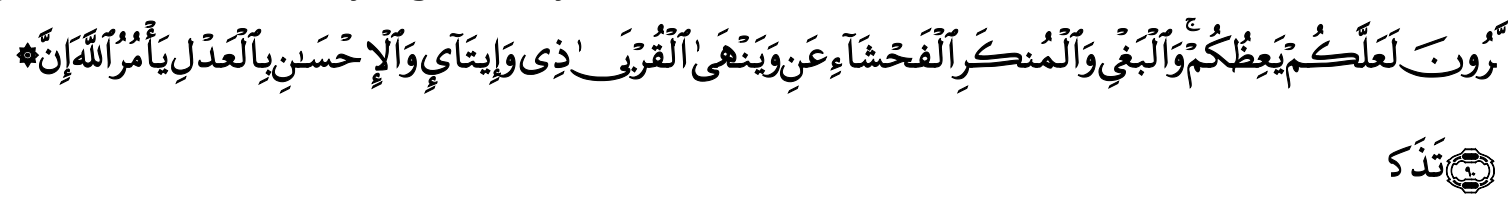

Artinya: Sesungguhnya Allah menyuruh (kamu) berlaku adil berbuat kebajikan, memberi bantuan kepada kerabat, dan Dia melarang (melakukan) perbuatan keji, kemungkaran, dan permusuhan. Dia memberi pengajaran kepadamu agar kamu dapat mengambil pelajaran. (QS. An-Nahl [16]: 90) ${ }^{14}$

M.Quraish Shihab dalam Tafsir Al-Misbah menafsirkan Al-Qur'an surah An-Nahl ayat 90 tersebut bahwa : sesungguhnya Allah secara terus-menerus memerintahkan siapapun di antara hamba-hamba Nya untuk berlaku adil dalam sikap, ucapan dan tindakan, walaupun terhadap diri sendiri dan menganjurkan berbuat ihsan yakni lebih utama dari keadilan dan juga pemberian apapun yang dibutuhkan sepanjang kemampuan lagi dengan tulus. ${ }^{15}$ Berdasarkan ayat Al-Qur'an surah An-Nahl ayat 90 serta penafsiran oleh M. Quraish Shihab tersebut jika dihubungkan dengan sikap dan perilaku pedagang ramuan tradisional suku Dayak dalam memberikan pelayanan terhadap konsumen pengguna ramuan tradisional tersebut menunjukkan bahwa ada kesesuaian dengan maksud penafsiran ayat tersebut yakni mereka berlaku adil

\footnotetext{
${ }^{11}$ Kusni Sulang, Belum Bahadathttp://jurnaltoddoppuli.wordpress.com/2012/04/25/belum-bahadat/ diakses 15 februari 2018

${ }^{12}$ Damianus Siyok dan Tiwi Erika, Mutiara Isen Mulang (Memahami Bumi dan Manusia Palangka Raya), Palangka Raya : PT. Sinar Begawan Khatulistiwa, 2014, hlm. 221.

${ }^{13}$ M. Yatimin Abdullah..., hlm. 538.

${ }^{14}$ Kementerian Agama RI, Al-Qur'an dan Terjemahan untuk Wanita, Jakarta Selatan : Penerbit Wali Oasis Terrace Recident, 2014 , hlm. 277.

${ }^{15}$ M.Quraish Shihab, Tafsir Al-Misbah(Pesan, Kesan, dan Keserasian Al-Qur'an) Volume 6, Jakarta : Lentera Hati, 2002 , hlm. 697.
} 
dalam sikap, ucapan dan tindakan, secara nyata kepada setiap orang yang menjadi pelanggan mereka dalam melakukan transaksi setiap harinya di pasar Kahayan.

\section{Etika Jual Beli Ramuan Tradisional Masyarakat Dayak di Pasar Kahayan Kota Palangka Raya}

Dari penelitian yang peneliti lakukan, ada beberapa fakta yang peneliti dapatkan. Antara lain filosofi Belom Bahadat artinya hidup bertata krama dan beradab hidup dalam kedamaian, kebersamaan, kesetaraan, keharmonisan, toleransi, menjunjung tinggi hukum dan kerja sama untuk meraih kesejahteraan bersama terlihat ketika para pedagang menghadapi komplen dari pembeli, pedagang menanggapi dengan sikap apa adanya dan berlapang dada. Bahkan lebih dari itu, pedagang menawarkan konsumen untuk memilik jenis ramuan lain yang sekiranya lebih cocok untuk dikonsumsi pembeli/konsumen. Ditinjau dari teori etika jual beli yang terfokus pada sudut pandang moral, peneliti dapat menilai bahwa disamping aspek ekonomi dari jual beli, terdapat aspek lain yang tidak kalah penting yang perlu diperhatikan pedagang yaitu aspek moral. Dinyatakan di dalam teori ini bahwa mengejar keuntungan sangat boleh dilakukan karena itulah tujuan dalam jual beli, tetapi tidak semata-mata hanya memperhatikan keuntungannya saja, tetapi perlu memandang bahwa kita harus menghormati kepentingan dan hak orang lain. Pantas diperhatikan lagi bahwa dengan itu kita sendiri tidak dirugikan. Sebaliknya, menghormati kepentingan dan hak orang lain harus dilakukan juga demi kepentingan jual beli itu sendiri. 16

Jika dihubungkan dengan prilaku etika jual beli yang dilakukan pedagang ramuan tradisional khas Dayak di Pasar Kahayan, nampak kesesuaian antara teori etika yang terfokus pada sudut pandang moral dengan sikap mereka (pedagang) dalam menanggapi komplen yang diajukan pembeli. Pedagang yang merupakan masyarakat asli suku Dayak menerima komplen dengan sikap lapang dada dan apa adanya. Selain itu juga mereka mengajukan ramuan lain untuk dicoba konsumen dalam perihal mengganti ramuan yang tidak cocok setelah dikonsumsi oleh pembeli. Pedagang memandang bahwa kegiatan jual-beli atau jual beli tidak semata-mata mencari keuntungan, tetapi sangat memperhatikan untuk menghindari sikap merugikan, dan menghormati hak orang lain (pembeli).

Sebagaimana dijelaskan dalam teori etika jual beli bahwa jual beli yang baik (good business) bukan saja jual beli yang semata-mata menguntungkan. Tetapi jual beli yang baik adalah juga memperhatikan yang baik secara moral. Malah harus ditekankan, arti moralnya merupakan salah satu arti terpenting bagi kata "baik". Suatu perbuatan dapat dinilai baik menurut arti terdalam justru kalau memenuhi standar etis itu. ${ }^{17}$ Hal ini memandang adanya keserasian antara standar etis atau moral dan prilaku pedagang ramuan tradisional khas Dayak di Pasar Kahayan yang merupakan masyarakat asli suku Dayak, mereka berpedoman dengan falsafah Belom Bahadat yang merupkan falsafah hidup masyarakat asli suku Dayak yang menyatakan bahwa "hidup beradat" merupakan prinsip paten yang harus mereka terapkan di segala aspek kehidupan mereka termasuk dalam kegiatan jual-beli atau jual beli yang mereka lakukan. Dari penelitian tersebut peneliti juga menganalisis bahwa terhadap prinsip tolongmenolong yang sangat kuat antara penjual dan pembeli. Tentunya hal ini memang sejalan dengan prinsip hidup masyarakat adat Dayak yang saling tolong-menolong terhadap sesama. Hal ini dikenal oleh masyarakat Dayak dengan slogan Handep tuntung haduhup artinya menanggulangi masalah bersama dan saling tolong-menolong. ${ }^{18}$

\footnotetext{
${ }^{16}$ K. Bertens, Pengantar Etika Bisnis, Yogyakarta : Penerbit Kanisius, 2000, hlm. 20.

${ }^{17}$ Ibid,

${ }^{18}$ Tjilik Riwut, Maneser Panatau Tatu Hiang (Menyelami Kekayaan Leluhur), Palangka Raya : Penerbit Pusakalima, 2003, hlm. 91.
} 
Ditinjau dari aspek penawaran barang, sepanjang perjalanan peneliti melakukan penelitian, salah satu konsumen menjelaskan bahwa masyarakat asli suku Dayak jika melakukan aktivitas jual beli atau berjualan cenderung apa adanya dalam menjelaskan barang yang mereka jual, tidak dilebih-lebihkan. Fakta ini jika dihubungkan dengan teori prinsip-prinsip etika jual beli, maka masyarakat asli suku Dayak dalam melakukan perdagangan ramuan tradisional di Pasar Kahayan memiliki salah satu prinsip etika jual beli yaitu prinsip kejujuran. Yang dimaksud yaitu kejujuran dalam penawaran barang atau jasa dengan mutu dan harga yang sebanding. ${ }^{19}$

Ditinjau dari teori asal usul suku Dayak bersamaan dengan penjelasan sifat suku Dayak, peneliti menganalisis bahwa etika masyarakat Dayak dalam berjual beli dilakukan dengan kejujuran, karena di dalam buku Tjilik Riwut yang berjudul Maneser Panatau Tatu Hiang dijelaskan zaman dulu pengaruh situasi alam yang ganas dan menantang tercermin dalam sikap dan gaya hidup suku Dayak dalam bermasyarakat. Selalu waspada, tegas tanpa basa-basi langsung pada tujuan. Hingga terkesan bertindak terlebih dahulu baru berfikir. Itulah sebabnya orang Dayak tidak mampu berpura-pura, mereka selalu bersikap apa adanya. Keramahan dan kemarahan terlihat jelas dalam sikap spontan yang terekspresi. ${ }^{20}$ Ditinjau dengan teori prinsipprinsip etika jual beli, jika dihubungkan dengan dengan prilaku atau cara berjual beli masyarakat asli suku Dayak dalam berdagang ramuan tradisional di Pasar Kahayan, maka prinsip otonomi yang terdapat dalam teori salah satu prinsip etika jual beli nampaknya sudah direalisasikan pedagang yang merupakan sikap dan kemampuan manusia untuk mengambil keputusan dan bertindak berdasarkan kesadarannya tentang apa yang dianggapnya baik untuk dilakukan. ${ }^{21}$ Teori ini tentu sejalur dengan fakta yang sudah peneliti tinjau di lapangan.

Selain itu, jika ada konsumen yang meminta ramuan, maka pedagang bersedia memberikan secara cuma-cuma. Hal ini lagi-lagi menguatkan bahwa prinsip hidup masyarakat Dayak adalah menonjolnya sikap tolong-menolong. Hal ini menjelaskan bahwah mencari keuntungan yang sebesar-besarnya bukanlah menjadi ambisi utama bagi mereka. Sampai pernah salah satu pembeli menyatakan bahwa jarang ada orang Dayak yang kaya raya, karena mereka berdagang hanya sekedar mencukupkan kebutuhan mereka dan sering memberi secara cuma-cuma ke orang yang memerlukan karena perasaan tidak tega.

\section{Jual Beli Ramuan Tradisional Masyarakat Dayak di Pasar Kahayan Kota Palangka Raya Perspektif Belom Bahadat dan Etika Bisnis Syariah}

Etika jual beli masyarakat adat Dayak khususnya penjual ramuan tradisional terdapat kesamaan terhadap konsep ekonomi Islam, seperti yang kita ketahui didalam teori Ekonomi Islam terdapat beberapa kriteria bagaimana sebuah jual beli dapat dikatakan sesuai dengan prinsip-prinsip Ekonomi Islam yaitu antara lain berlandaskan prinsip Ketuhanan, rahmatan lil 'alamin (rahmat bagi seluruh alam), tahqiq 'adl (mewujudkan keadilan), nubuwwah (kenabian), as-siddiq (transparansi), freedom to act (kebebasan bertindak dan berusaha) dan socio-profit oriented. Ekonomi Islam meletakkan manusia sebagai khalifah dimuka bumi ini dimana segala bahan-bahan yang ada dibumi dan di langit adalah diperuntukkan untuk manusia. ${ }^{22}$ Sebagaimana firman Allah SWT:

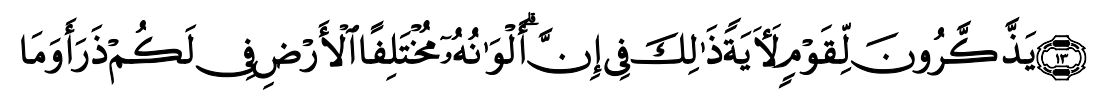

\footnotetext{
${ }^{19}$ Agus Arijanto,Etika Bisnis bagi Pelaku Bisnis, Jakarta : PT. Rajagrafindo Persada, 2008, hlm. 12.

${ }^{20}$ Tjilik Riwut...,hlm. 93.

${ }^{21}$ Agus Arijanto...,hlm. 13.

${ }^{22}$ Ibid,
} 
Artinya: dan Dia (menundukkan pula) apa yang Dia ciptakan untuk kamu di bumi ini dengan berlain-lainan macamnya. Sesungguhnya pada yang demikian itu benar-benar terdapat tanda (kekuasaan Allah) bagi kaum yang mengambil pelajaran. (QS. An-Nahl [16]: $13)^{23}$

M. Quraish Shihab dalam Tafsir Al-Misbah menjelaskan bahwa maksud ayat ini adalah selain yang telah diciptakan oleh Allah dilangit dan disediakan untuk manfaat manusia. Dia juga menciptakan berbagai macam binatang, tumbuhan dan benda di muka bumi untuk para manusia. Semua itu diciptakan untuk manusia manfaatkan. Sesungguhnya pada yang demikian itu terdapat tanda-tanda yang jelas dan banyak bagi kaum yang selalu merenungkan hingga mengetahui kekuasaan sang pencipta dan kasih sayangnya kepada hamba-hambanya. ${ }^{24}$

Berdasarkan ayat Al-Qur'an surah An-Nahl ayat 13 serta penafsiran oleh M. Quraish Shihab diatas jika dihubungkan dengan aktivitas berdagang masyarakat suku Dayak dalam menjual ramuan tradisional di Pasar Kahayan bahwa ada kesesuaian dengan maksud penafsiran ayat tersebut yakni pedagang ramuan tradisional khas Dayak sebagai seorang insan dikaruniai berbagai macam sumber daya alam dan pikiran yang dianugrahkan kepada manusia untuk dimanfaatkan sebagai salah satu cara dalam mempertahankan dan melanjutkan hidup untuk mencari rezeki. Selain untuk dapat dikonsumsi sendiri sebagai obat dalam menyembuhkan berbagai macam penyakit dan gangguan kesehatan, juga sebagai salah satu sumber mata pencaharian terkhusus masyarakat adat Dayak yang memiliki keahlian khusus dalam mengetahui jenis-jenis tumbuhan yang dapat dijadikan ramuan tradisional.

Manusia sebagai makhluk ciptaan Allah SWT yang paling sempurna dari makhluk lainnya, mengemban amanah yaitu sebagai khalifah dimuka bumi untuk menjaga dan memanfaatkan dengan sebaik-baiknya hasil alam, antara lain hasil hutan yang salah satunya merupakan tumbuh-tumbuhan yang bisa dijadikan ramuan tradisional khas suku Dayak. Sesuai dengan firman Allah SWT yang berbunyi:

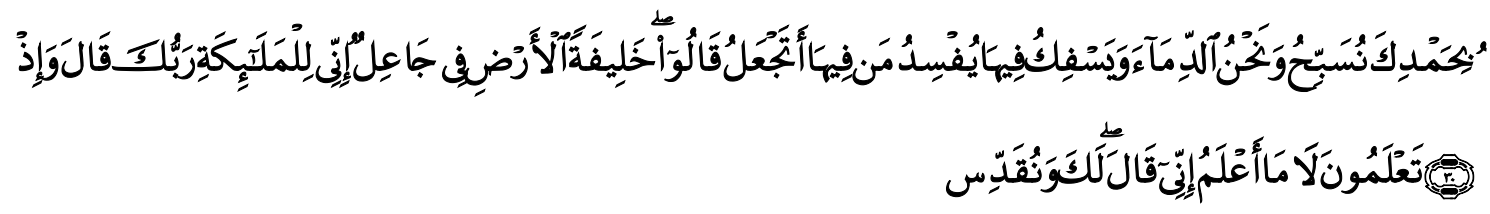

Artinya: Ingatlah ketika Tuhanmu berfirman kepada para malaikat, "sesungguhnya Aku hendak menjadikan satu khalifah di muka bumi." Mereka berkata, "apakah Engkau hendak menjadikan di bumi itu siapa yang akan membuat kerusakan padanya dan menumpahkan darah, padahal kami senantiasa bertasbih dengan memuji-Mu dan menyucikan-Mu?" Tuhan berfirman, "sesungguhnya Aku mengetahui apa yang tidak kamu ketahui." (QS. AlBaqarah [2] : 3025

M. Quraish Shihab dalam Tafsir Al-Misbah menjelaskan bahwa ayat ini menunjukkan bahwa kekhalifahan terdiri dari wewenang yang dianugrahkan Allah SWT, makhluk yang diserahi tugas, yakni Adam as dan anak cucunya, serta wilayah tempat bertugas, yakni bumi yang terhampar ini. Jika demikian, kekhalifahan mengharuskan makhluk yang diserahi tugas itu melaksanakan tugasnya sesuai dengan petunjuk Allah yang memberinya tugas dan wewenang.

\footnotetext{
${ }^{23}$ Kementerian Agama RI, Al-Qur'an dan Terjemahan ..,hlm. 268.

${ }^{24}$ M. Quraish Shihab...,hlm. 546.

${ }^{25}$ Kementerian Agama RI.., hlm. 6.
} 
Kebijaksanaan yang tidak sesuai dengan kehendak-Nya adalah pelanggaran terhadap makna dan tugas kekhalifahan. ${ }^{26}$

Selanjutnya jika dihubungkan dengan teori Ekonomi Islam, dinyatakan bahwa semua aktivitas ekonomi dan memanfaatkan hasil alam untuk mempertahankan hidup termasuk jualbeli merupakan tugas manusia sebagai khalifah dimuka bumi yang bertujuan untuk beribadah kepada Allah SWT. Di dalam Islam, harta bukanlah merupakan tujuan hidup tetapi sekedar wasilah atau perantara bagi mewujudkan perintah Allah Swt. ${ }^{27}$ Jika dihubungkan dengan perilaku masyarakat asli suku Dayak dalam berdagang ramuan tradisional khas Dayak di Pasar Kahayan terdapat kesesuaian antara prilaku mereka dengan substansi Ekonomi Islam yang sesungguhnya, bahwa di sepanjang perjalanan penelitian yang dilakukan oleh peneliti, mencari keuntungan yang sebesar-besarnya bukanlah tujuan utama masyarakat Dayak dalam berdagang ramuan tradisional, tetapi mereka memiliki maksud lain yang lebih mulia yaitu dapat membantu sesama dan memegang kuat prinsip tolong-menolong sebagaimana sesuai dengan falsafah hidup mereka yaitu yang kita kenal dengan sebutan falsafah Belom Bahadat. Selain itu, meskipun tidak semua pedagang beragama Islam, tetapi mereka sepakat bahwa setiap perbuatan baik yang mereka lakukan didunia akan diberikan ganjaran dan balasan dari Tuhannya.

Islam mengajarkan keyakinan tentang hari kemudian, yang mengharuskan manusia dilarang merebut hak orang lain. Hal ini yang menjadi prinsip syariah, bahwa meski Allah SWT mungkin mengampuni kesalahan yang dilakukan terhadap hak-Nya (lalai beribadah, misalnya), Dia tak mengampuni kejahatan yang dilakukan seseorang terhadap sesamanya atau bahkan kepada makhluk lainnya. Hal ini jika dihubungkan dengan etika jual beli yang dilakukan oleh masyarakat asli suku Dayak dapat peneliti tangkap bahwa terdapat kesesuaian antara prinsip Ekonomi Islam dengan etika jual beli yang mereka lakukan. Seperti contoh masyarakat Dayak dalam berdagang ramuan tradisional menjelaskan dan mempromosikan produk atau ramuan yang mereka jual dengan tidak dilebih-lebihkan atau diada-adakan. Mereka cenderung dan seringkali bersikap apa adanya sesuai dengan watak asli yang mereka miliki dari turun-temurun orang asli suku Dayak. ${ }^{28} \mathrm{Hal}$ ini dapat dikatakan bahwa tidak melebih-lebihkan dalam penjelasan dan penawaran barang kepada pembeli merupakan salah satu cerminan sikap bahwa mereka yakin tentang hari kemudian yang akan diadakannya hari pembalasan atas semua kejahatan yang dilakukan didunia, dan sikap apanya mereka (pedagang) mencerminkan betapa di perhatiannya terhadap hak orang lain.

Beberapa norma-norma penting dalam kajian Ekonomi Islam jika berbicara tentang etika jual beli, peneliti sedikit kesulitan menjelaskan dan menggambarkan, bahkan peneliti juga kesulitan menuangkan apa yang peneliti pikirkan dan lihat secara realita dengan tulisan, tetapi jika di hubungkan dengan kajian Ekonomi Islam yaitu dengan melihat etika jual beli masyarakat adat Dayak, kurang lebih peneliti menangkap adanya beberapa kesamaan diantara terdapat adanya prinsip Ketuhanan, prinsip rahmatan lil alamin, prinsip tahqiq 'adl yaitu mewujudkan keadilan terhadap sesama, prinsip as-siddiq atau transparansi yang tercermin dari cara masyarakat Dayak dalam menawarkan barang yang dijualnya, prinsip freedom to act yaitu kebebasan bertindak dan berusaha, dan prinsip socio-profit oriented.

\section{PENUTUP}

Praktik jual beli masyarakat Dayak dalam menjual ramuan tradisional di Pasar Kahayan Kota Palangka Raya dilakukan para pedagang yang berumur di atas 55 tahun dikarenakan

\footnotetext{
${ }^{26}$ M. Quraish Shihab, Volume 1..,hlm. 173.

27Veithzal Rivai, Amiur Nuruddin, dan Faisar Ananda...,hlm. 393.

${ }^{28}$ Ibid, hlm. 397.
} 
kematangan pengetahuan yang dimiliki para pedagang, selain itu tidak semua masyarakat asli suku Dayak memiliki pengetahuan tentang ramuan tradisional ini, karena tidak ada sumber tertulis yang dapat dijadikan pedoman mereka. Hanya mengandalkan bakat turun-temurun dari para leluhur mereka.

Etika jual beli masyarakat Dayak dalam berdagang ramuan tradisional adalah terdapat penerapan falsafah Belom Bahadat pada praktik jual beli mereka. Peneliti menyimpulkan terdapat prinsip tolong-menolong yang amat kuat dan dijunjung tinggi oleh pedagang yang merupakan masyarakat adat Dayak, dengan slogan mereka yaitu Handep tuntung haduhup yang artinya menanggulangi masalah bersama dan saling tolong-menolong.

Jual beli ramuan tradisional masyarakat dayak di Pasar Kahayan Kota Palangka Raya perspektif belom bahadat dan etika bisnis syariah terdapat adanya kesamaan antara filosofi Belom Bahadat yaitu hidup bertata krama dan beradab dan hidup dalam kedamaian, kebersamaan, kesetaraan, keharmonisan, toleransi, menjunjung tinggi hukum dan kerja sama untuk meraih kesejahteraan bersama yang diaplikasikan dalam etika jual beli masyarakat Dayak dalam berdagang ramuan tradisional dengan etika bisnis syariah antara lain adanya prinsip Ketuhanan, rahmatan lil alamin (rahmat bagi seluruh alam), tahqiq 'adl (mewujudkan keadilan), nubuwwah (kenabian). As-siddiq (transparansi), freedom to act (kebebasan dalam bertindak dan berusaha) dan socio-profit oriented.

\section{DAFTAR PUSTAKA}

Abdullah, Yatimin. Pengantar Studi Etika, Jakarta: PT. Raja Grafindo Persada, 2006.

Ardiansyah, Panji. Etika Jual beli (Bagaimana Membangun Jual beli yang Beretika), Bantul Yogyakarta: PT. Anak Hebat Indonesia, 2017.

Ardiansyah, Panji. Etika Jual beli (Bagaimana Membangun Jual beli yang Beretika), Bantul Yogyakarta : Quadrant, 2017.

Arijanto, Agus. Etika Jual beli bagi Pelaku Jual beli, Jakarta: PT. Rajagrafindo Persada, 2008.

Badan Perencana Pembangunan Daerah Kota Palangka Raya dan Badan Pusat Statistik Kota Palangka Raya, Kota Palangka Raya Dalam Angka (Palangka Raya City In Figures 2007, Palangka Raya: Grahamedia Design, 2007.

Batuallo, Salmon. Peranan Nilai Budaya Masyarakat Dayak Ngaju dalam Memelihara Lingkungan Di Provinsi Kalimantan Tengah, Pontianak : Balai Pelestarian Sejarah dan Nilai Tradisional Pontianak, 2009.

Bertens, K. Pengantar Etika Jual beli, Yogyakarta : Penerbit Kanisius, 2000.

Bungin, Burhan. Analisis Data Penelitian Kualitatif, Jakarta : PT. Raja Grafindo Persada, 2003.

Dakhoir, Ahmad dan Itsla Yunisva Aviva. Ekonomi Islam dan Mekanisme Pasar (Refleksi pemikiran Ibnu Taymiyah), Jawa Timur: LaksBang Pressindo, 2017.

Darmanto, Muhammad. Praktik Etika dalam Transaksi Jual beli Masyarakat Muslim, Palangka Raya: STAIN Palangka Raya, 2011. 
Elmubarok, Zaim. Membumikan Pendidikan Nilai (Pengumpulkan yang terserak, menyambung yang terputus, dan menyatukan yang tercerai, Bandung: Penerbit Alfabeta, 2008.

Fathoni, Abdurrahman. Metodologi Penelitian \& Teknik Penyusunan Skripsi, Jakarta : PT. Rineka Cipte, 2011.

Ibrahim. Metodologi Penelitian Kualitatif ( Panduan Peneliti beserta Contoh ProposaL Kualitatif), Bandung : Penerbit Alfabeta, 2015.

Kementerian Agama RI, Al-Qur'an dan Terjemahan untuk Wanita, Jakarta Selatan : Penerbit Wali Oasis Terrace Recident, 2014.

Keraf, Sonny. Etika Jual beli (Tuntunan dan Relevansinya), Yogyakarta :Penerbit Kanisius, 1998.

Khasanah, Nur. Etika Jual beli Perusahaan Industri Kecil Makanan Kering (Studi kasus di Kelurahan Menteng Kecamatan Jekan Raya kota Palangka Raya), Palangka Raya: STAIN Palangka Raya, 2014.

Kota Palangka Raya, Pemerintah, Selayang Pandang Kota Palangka Raya Tahun 2016, Palangka Raya: 2006.

Kusni Sulang, Belum Bahadathttp://jurnaltoddoppuli.wordpress.com/2012/04/25/belumbahadat/ Diakses 15 Februari 2016.

Ma'ruf, Muhammad. Etika Jual beli Pedagang Muslim Suku Banjar di Samuda, Palangka Raya: STAIN Palangka Raya, 2012.

Miskawaih, Ibnu. Menuju Kesempurnaan Akhlak, Cet 3, Bandung: Mizan, 1995.

Moelong, Lexy. Metodologi Penelitian Kualitatif, Bandung : PT. Remaja Rosdakarya, 2015.

Muhammad Aldio, Sejarah Kota Palangka Raya, Kalimantan Tengah (1950-1972) http://coretcoretdoang.blogspot.co.id/2015/10/sejarah-kota-palangka-raya-kalimantan.html, diakses pada tanggal 07-05-2018.

Normuslim. Kerukunan Antarumat Beragama Keluarga Suku Dayak Ngaju, Palangka Raya : Penerbit Lembaga Dayak, 2014.

Pelu, Ibnu Elmi A.S., dan Jefry Tarantang. Interkoneksi Nilai-Nilai Huma Betang Kalimantan Tengah dengan Pancasila, Jurnal Studi Agama dan Masyarakat, Volume 14, Nomor 2, Desember 2018.

Rivai,Veithzal, dkk. Islamic Business and Economic Ethics (Mengacu pada Al-Qur'an dan Mengikuti Jejak Rasulullah Saw dalam Jual beli, Keuangan, dan Ekonomi, Jakarta: PT. Bumi Aksara, 2012.

Sanaman Mantikei, Tjilik Riwut. Maneser Panatau Tatu Hiang (Menyelami Kekayaan Leluhur), Palangka Raya : Penerbit Pusakalima, 2003. 
Shihab, M. Quraish. Tafsir Al-Misbah (Pesan, Kesan, dan Keserasian Al-Qur'an) Volume 6, Jakarta : Lentera Hati, 2002.

Shihab, M. Quraish. Tafsir Al-Misbah (Pesan, Kesan, dan Keserasian Al-Qur'an) Volume 1, Jakarta : Lentera Hati, 2002.

Shihab, M. Quraish. Tafsir Al-Misbah (Pesan, Kesan, dan Keserasian Al-Qur'an) Volume 3, Jakarta : Lentera Hati, 2002.

Shihab, M. Quraish. Tafsir Al-Misbah (Pesan, Kesan, dan Keserasian Al-Qur'an) Volume 2, Jakarta : Lentera Hati, 2002.

Siyok, Damianus, dan Etika, Tiwi. Mutiara Isen Mulang (Memahami Bumi dan Manusia Palangka Raya), Palangka Raya : PT. Sinar Bagawan Khatulistiwa, 2014.

Sugiyono. Metode Pelenitian Jual beli (Pendekatan Kuantitatif, Kualitatif, dan R\&D), Bandung : Penerbit Alfabeta, 2012.

Suprayogo, Imam, dan Tobroni. Metodologi Penelitian Sosial-Agama, Bandung: PT. Remaja Rosdakarya, 2003.

T.T Suan dan Sulang, Kusni, dkk. Budaya Dayak Permasalahan dan Alternatif (Berdiri di Kampung Halaman Memandang Tanah Air Merangkul Dunia), Malang : Bayumedia, 2011.

Tarantang, Jefry. Menggali Etika Pengacara dalam Alquran, Jurnal Studi Agama dan Masyarakat, Volume 11, Nomor 2, Desember 2015.

Tarmizi, Erwandi. Harta Haram Muamalat Kontemporer, Bogor : PT. Berkat Mulia Insani, 2016. 